УДК 658

I.C. Negru
R.I. Negru

\title{
THE INTERDEPENDENCE BETWEEN PRODUCTION MANAGEMENT AND LOGISTICS
}

Modern trends in production management have increased the importance of the time factor in both production and logistics. However, there is much less room for maneuver in production than in logistics. Therefore, to reduce the duration of the main production cycle, many companies are trying to improve intra-production logistics by introducing new technologies and logistics systems. Of decisive importance for production management is the activity of supplying the necessary materials, including logistics operations.

In this context, it is worth mentioning that at the present stage the basic links between production management and logistics have been concentrated by specialists in a new field that has been defined as logistics management. According to the Council of Supply Chain Management Professionals, "Logistics management is an integration function that coordinates and optimizes all logistics activities, as well as integrates logistics activities with other functions, including marketing, sales production, finance and information technology."(Supply Chain Management Definitions and Glossary, 2020).

We believe that the concept of logistics management best meets all the links between production management and logistics.

Key words: production management, logistics, logistics management, transport operations, supply, stocks, “Just in Time" concept, LEAN production.

DOI 10.34079/2226-2822-2020-10-20-25-30

The interdependence between production management and logistics should be considered, first of all, from the perspective of logistical support for production, as well as the management of stocks of materials, unfinished production and finished products in the activity of an industrial enterprise. At the same time, the logistics is called to ensure the management of transport operations throughout the technological process, as well as the management of the company's warehouses, etc.

In turn, the management of the production activity applies the general management knowledge in the field of production of the industrial unit, in order to properly manage resources and adapt production to market requirements. (Cotelnic, 2003, p.4).

Here we must make some clarifications regarding the principles of organization of industrial production, which involve a set of economic and technical-organizational measures, regarding the establishment, provision and coordination of means of production and labor in such a way that the manufacture of products to be carried out in the best conditions.

The scientific organization of the production process in industrial enterprises must ensure through the methods and techniques of organization used the observance of some basic organization principles: (Cotelnic, 2003, pp.23-24)

1) The principle of proportionality emphasizes the need for certain proportions in order to ensure continuity and rhythm in the organization of the production process depending on the productivity of the workers or the efficiency of the machine.

Failure to comply with this principle and therefore non-compliance with the necessary numerical proportions between different groups of workers or machine systems leads to the appearance of narrow places or surpluses at the level of different production links. New 
technologies and changes in the organization of production lead to changes in the productivity of groups of workers or in the efficiency of groups of machines, which require the operational adaptation of such measures to restore the necessary proportionality between them. The proportionality coefficient can be calculated as the ratio between the minimum and maximum productivity. The size of this coefficient must tend towards unity.

2) The principle of rhythmicity expresses the requirement to ensure the necessary conditions that allow the repetition at well determined intervals in accordance with the cadence of manufacture of the same works, at the same jobs.

3) The principle of parallelism in the organization of production consists in the simultaneous execution of different parts of a product or products, as well as of different parts of the production process - phases, operations, stages. In the conditions of a superior organization of the production, the development in parallel of the different phases or operations imposes as a necessary condition the existence of a certain synchronization in their execution in order to obtain at the fixed terms the finished production.

4) The principle of the straight line - that in the design of the technological process to ensure the shortest way in the passage of different raw or auxiliary materials from one section to another.

This presupposes that the flow of materials has a continuous character, to be as short as possible, avoiding turns, opposite directions or intersections. The coefficient that characterizes this principle is the coefficient of the straight line, which is calculated as a ratio between the optimal size of the road to be traveled in order to achieve the technological process and the actual size. The size of this coefficient must tend to one.

5) The principle of continuity consists in ensuring the development of the production process without interruptions or with interruptions as small as possible in time, on all phases of the production process. In general, the result of the interaction of logistics with production management is manifested by a comparison of the traditional and logistical approach in the process of organizing production (Figure 1).

At the same time, the logistical approach also advances certain requirements towards production management, such as:

- the possibility of a lower degree of complexity of the product and maximum simplicity of its design;

- a greater number of technological operations performed in a single job, minimizing the time of preparatory and final operations; workplace;

- small batches of machined parts, minimizing their processing expectations at the

- lower interoperable stocks.

The interaction between production management and logistics is also determined by the duration of the main production cycle. Reducing production time and technology cycle is one of the main logistics tasks for those companies that apply the concepts of "JIT" (just in time) or "LEAN production".

However, if large stocks of finished products are created in the company's distribution networks, then it is not necessary to impose a reduction in the duration of the production cycle. This is how the relationship between internal production and external logistics manifests itself. 


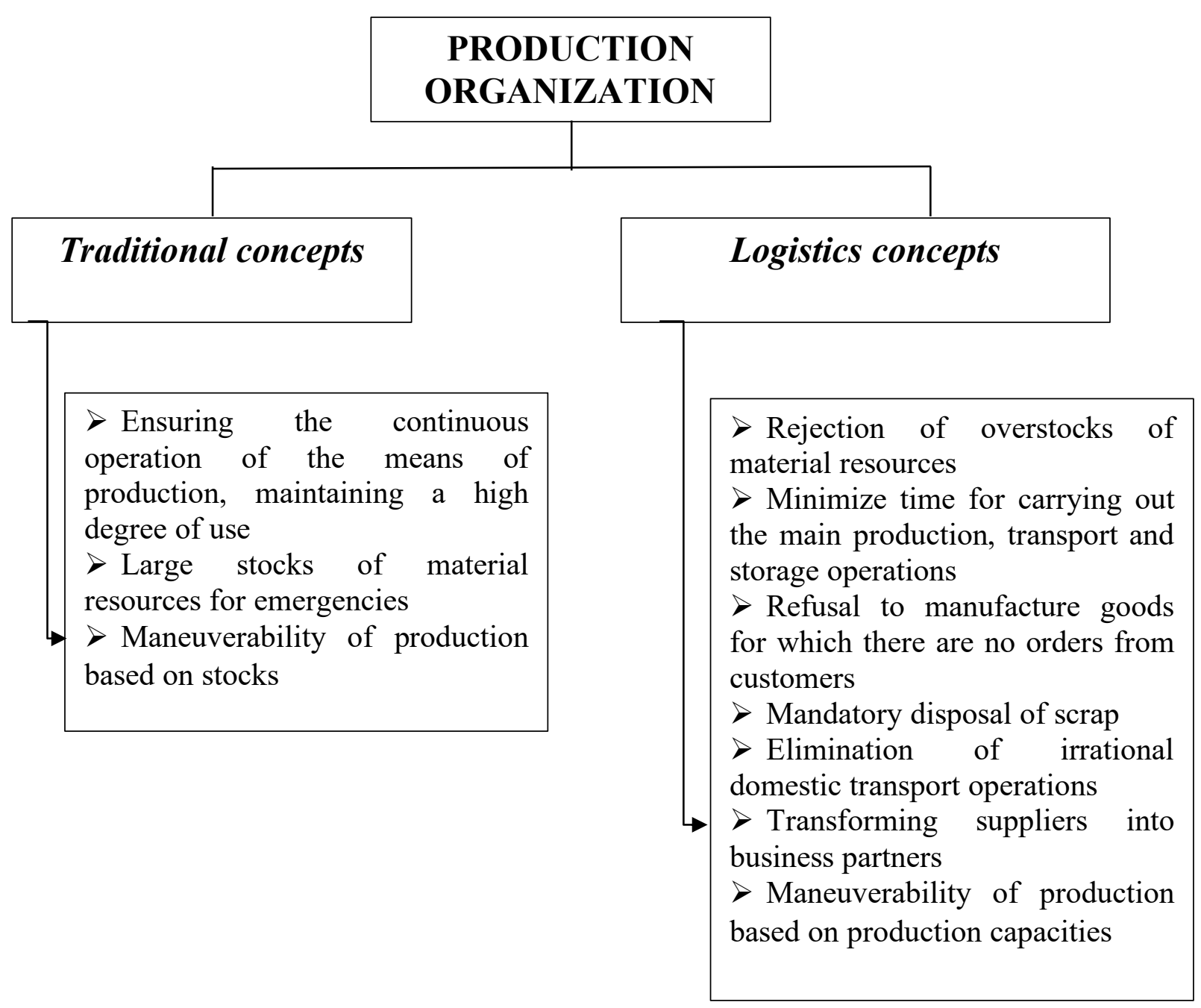

Figure 1. Traditional and logistical concepts of production organization Source: adapted after Григорьев, М.Н. и Уваров, С.A., 2012.

In the case of JIT production systems, by scheduling the production a communication is made regarding the production to be carried out both inside the enterprise and outside it, to the suppliers. Better production scheduling contributes to improving the company's ability to meet customer requirements by reducing inventory levels by operating in smaller batches.

There are several production planning tactics in JIT systems:

1) communication of production scheduling to suppliers;

2) elimination of waste;

3) use of the "Kanban" technique;

4) production in small batches;

5) performing, after each operation, a control of the part to make sure that it is good.

In turn, LEAN production means identifying the value perceived by consumers by analyzing all activities that lead to the realization of the product or service and then optimizing the whole process from their point of view. The major difference between JIT and LEAN production is that JIT is a philosophy of continuous improvement by focusing on an 
organization's internal efforts, while LEAN production focuses primarily on consumer requirements.

It should be noted that the application of the LEAN production concept requires the observance of 4 basic principles:

1. Activities must be fully specified in terms of time, content, sequence and outcome.

2. Each customer-supplier contact, both inside and outside, must be clearly defined by specifying the persons involved, the methods, the durations and the quantities of goods or services provided.

3. The flows of products and services must be simple and direct, ie the goods and services will be directed directly to the people or machines where they are needed.

4. Any improvement in the system must be made in accordance with the "scientific method" at the lowest level of the enterprise.

The LEAN system requires that the activities, connections and flows of bag parts subassemblies be monitored so that any problems are autocratically detected. Therefore, JIT insists on continuous improvement of processes and products, LEAN production on understanding consumer requirements and on lifelong learning, staff development in a specific assembly line environment.

The transition of an enterprise to LEAN production is difficult. Building an organizational culture in which learning and continuous improvement of performance as norms is a great challenge. However, companies that focus on JIT, quality and staff development can be considered as LEAN. LEAN production companies adopt a philosophy of minimizing waste through their efforts for improvement through lifelong learning, creativity and teamwork.

In the efforts of an enterprise to adopt the LEAN production system, some essential attributes can be used to verify and determine the degree of adaptation to this type of production. These attributes can determine the extent to which an enterprise has implemented the LEAN system.

The following are some key attributes: (Militaru, 2008, p.188)

$\checkmark$ Selection / separation - keep only what is necessary and remove the rest from the production area. Items without value are identified and removed. By eliminating them, the available space is created and the flow of activities can be improved.

$\checkmark$ Simplification - the use of methods or tools to improve business flows and reduce waste. Ergonomic elements or those of labeling and visual presentation of information are taken into account, in order to be easier to use when the production area is needed.

$\checkmark$ Cleanliness - maintaining a clean production environment by eliminating dirt and toxins.

$\checkmark$ Standardization - eliminating variations in processes by developing standard operating procedures. The use of standardized equipment and tools can reduce training time and costs. Training and improvement of work teams to deal with problems that occur in the production area. motivation;

$\checkmark$ Support / self-discipline - regular review to identify employee efforts and their proper company.

$\checkmark$ Safety - developing a set of good practices to ensure safety in the workplace in the

Identifying ways in which waste can occur and developing effective measures to eliminate or reduce waste is a challenge for all businesses. These include:

$>$ Overproduction - occurs more than customers order or earlier than delivery times;

$>$ Queues - unused time, storage and waiting for parts, their subassemblies or finished products to be processed, assembled or delivered;

$>$ Transport - the movement of raw materials between factories, jobs, production centers and their handling several times; 
products stored;

Stocks - raw materials that are not needed, production in progress or finished

$>$ Movements - the movement of people or equipment that does not add value;

$>$ Defective products;

$>$ Unnecessary processing - performing additional operations, which do not add value, are unnecessary and are a waste for the organization.

In conclusion, if production processes involve activities that do not add value from a consumer perspective, then they are a form of waste for the enterprise.

Of particular importance for the interaction between production management and logistics is the planning function, which has acquired integrated features in this context.

The objectives of planning in these areas are quite diverse, but the main ones can be:

* providing services to customers in accordance with their business strategy;

* supporting the necessary speed of goods flow, stimulating sales by delivering

products to the market on time, as well as minimizing expiration costs;

* minimizing costs for deliveries, production, physical distribution;

* minimal use of the company's assets, etc.

In conclusion, we could argue that the common features of both production management and logistics could be merged through logistics management.

\section{Бібліографічний список}

Григорьев, М.Н. и Уваров, С.А., 2012. Взаимодействие логистики с операционным (производственным) менеджментом. В: Григорьев М.Н. и Уваров С.А., 2012. Логистика. 3-е изд. Москва: Юрайт.

Cotelnic, A., 2003. Managementul activității de producție. Chişinău: Evrica.

Militaru, Gh., 2008. Managementul producției și al operațiunilor. București: All.

Supply Chain Management Definitions and Glossary, 2020. Council of Supply Chain Management Professionals (CSCMP). [online] Available at: $<$ https://cscmp.org/CSCMP/Educate/SCM_Definitions_and_Glossary_of_Terms.as px $>$ (Accessed 10 September 2020).

\section{References}

Cotelnic, A., 2003. Managementul activității de producție [Production activity management]. Chisinau: Evrica.

CSCMP Supply Chain Management Definitions and Glossary,2020. Council of Supply Chain Management Professionals (CSCMP). [online] Available at: $<$ https://cscmp.org/CSCMP/Educate/SCM_Definitions_and_Glossary_of_Terms.as $\mathrm{px}>$ (Accessed 10 September 2020).

Grigorev, M.N. and Uvarov, S.A., 2012. Vzaimodeystvie logistiki s operatsionnym (proizvodstvennym) menedzhmentom [Interaction of logistics with operational (production) management]. In: Grigorev, M.N. and Uvarov, S.A., 2012. Logistics. $3^{\text {rd }}$ ed. Moskva: Yurayt.

Militaru, Gh., 2008. Managementul producției și al operațiunilor [Production and operations management]. București: All.

Стаття надійшла до редакції 21.09.2020. 
I.K. Негру

P.I. Негру

ВЗАСМОЗАЛЕЖНІСТЬ МІЖ МЕНЕДЖМЕНТОМ ВИРОБНИЦТВА I ЛОГІСТИКОЮ

Стаття присвячена висвітленню основних аспектів взаємодї управління виробництвом та логістики в сучасних умовах. У більшості сучасних компаній відповідальність за підтримання необхідних рівнів запасів матеріальних ресурсів на виробництві перекладається на логістичний персонал, щзо означає розширення меж логістичної взаємодї з менеджментом виробництва/операчіями. 3 метою ефективного управління постачанням матеріальних ресурсів на практиці встановлено, що технічна та економічна оцінка зовнішніх виробничих послуг та матеріальних ресурсів, щзо надходять у виробниче споживання, очінка існуючих та потенційних постачальників, включаючи оцінку системи, є необхідною складовою стратегії закупівель, а також оцінки стратегії закупівель.

Керівництво виробництвом має забезпечити за допомогою методів і прийомів організації дотримання деяких основних принципів організації, таких як: принцип пропориійності, принциип ритмічності, принциип паралельності, принцип прямолінійності та принцип безперервності.

Результат взаємодії логістики з управлінням виробництвом проявляється у порівнянні традииійного та логістичного підходу до процесу організації виробництва. Взаємодія управління виробництвом та логістики визначається також тривалістю основного виробничого ичиклу. Скорочення часу виробництва та технологічного циклу $\epsilon$ одним з основних логістичних завдань для тих компаній, які застосовують поняття «Вчасно» або «Ощчадливе виробництво».

У той же час основним елементом взаємодії управління виробництвом та логістики є функиія планування, яка набула в результаті иүієї взаємодії інтегрованих характеристик.

Ключові слова: управління виробництвом, логістика, управління логістикою, транспортні операції, постачання, запаси, концепџія «Вчасно», «Ощуадлиее виробництво».

УДК 336.14:352

\section{Kyslova}

A. Severina

\section{BUDGET DECENTRALIZATION: SOCIO-ECONOMIC SIGNIFICANCE AND ITS IMPACT ON LOCAL BUDGETS}

The article explains the concept and the essence of budget decentralization, summarizes some changes in the budget legislation of Ukraine and the peculiarities of the introduction of budget decentralization at the present stage, the essence and the significance of the reform for Ukraine as a state with pro-European views. Positive and negative tendencies of budgetary and financial decentralization are characterized, the basic problems of the formation and the effective use of budgetary funds at the level of the regions, the sources of the incomes and the orientation of the expenses of the local budgets are investigated. The role of local taxes and fees in the filling of the local budgets, the dynamics of their growth compared to the previous years is analyzed. The main problematic issues that create risks for the systematic completion of the reform, including the reform of the administrative-territorial system, are identified, 